\title{
Characteristics of heat flow and geothermal fields in Ruidian, Western Yunnan Province, China
}

\author{
Junjie $\mathrm{Ba}^{1}$, Chuntian $\mathrm{Su}^{1}$, Yanqing $\mathrm{Li}^{1}$, Shuiyun $\mathrm{Tu}^{2 *}$ \\ ${ }^{1}$ Institute of Karst Geology, CAGS/Key Laboratory of Karst Dynamics, MNR\&GZAR, Guilin 541004, China \\ ${ }^{2}$ Yunnan Geological Engineering Exploration Group Co. Ltd., Kunming 650041, China
}

Corresponding Author Email: tushuiyun7712@163.com

https://doi.org/10.18280/ijht.360407

Received: 19 January 2018

Accepted: 18 June 2018

\section{Keywords:}

ruidian geothermal field, reservoir temperature, heat flow, geothermal gradient

\begin{abstract}
As an important parameter, the temperature of the thermal reservoir is essential to the classification of the geothermal system and the potential of geothermal resources. The inversion coupling study of the geothermal field is an important basis for establishing the genetic model for the geothermal field of Ruidian, Western Yunnan Province, China. With a geothermal flow of up to $120.5 \mathrm{~mW} / \mathrm{m}^{2}$, and an average geothermal gradient of $4.61^{\circ} \mathrm{C} / 100 \mathrm{~m}$, the Tengchong-Ruidian area is a high temperature geothermal area, where the highest hot spring water temperature can reach $91.5^{\circ} \mathrm{C}$. The geothermal reservoirs there can be divided into shallow and deep thermal reservoirs. By using the $\log (\mathrm{Q} / \mathrm{K})$ curve method and the Na$\mathrm{K}-\mathrm{Mg}$ triangle diagram method, this paper finds that the underground hot water in the study area is in an unsaturated state and mixed with cold water. Then it calculates the thermal reservoir temperature and analyzes the deep temperature characteristics of the subsurface thermal fluid and the mixing process of the hot and cold water using the $\mathrm{SiO}_{2}$ solubility geothermometer, the dissolved chloride-enthalpy plot, the dissolved silica-enthalpy graph, and the linear regression equations iteration solution methods. The conclusion obtained from this study is that the temperature of the shallow thermal reservoir is about $145^{\circ} \mathrm{C}$, that the temperature of the deep thermal reservoir about $220^{\circ} \mathrm{C}$, and that the proportion of cold water mixed generally between $60 \%$ and $70 \%$. The comprehensive research results of the temperature field in the study area provide theoretical and data support for the establishment of the genetic mechanism for the Ruidian geothermal field.
\end{abstract}

\section{INTRODUCTION}

China reserves the second largest amount of geothermal resources in the world, which has a significant prospect for development and utilization. With the traditional energy running short, the need for clean energy is becoming more urgent, leading to more and more attention to the development and utilization of geothermal energy. Currently, the development and utilization of geothermal energy is increasing at a rate of $10 \%$ per year in China [1-2]. Due to the great development potential and broad prospects, the sustainable development and utilization has become the most critical issue in the geothermal industry around the world [34]. However, the reservoir temperature in the Ruidian geothermal field, as the key parameter in the research and development of underground hot water, is difficult to measure directly [5-6].

The determination of the heat storage temperature is mainly accomplished by two methods: direct measurement method and temperature calculation method. The former delivers more accurate data, but it is also time consuming and costly. Therefore, in most cases, the temperature calculation method is used to obtain the heat storage temperature [7]. Currently, the geothermal thermometric scale /geothermometer approach is an economical and effective way to obtain this parameter. It has been widely used in estimating temperatures, including cationic, silica, gas chemistry and isotope geothermometers [8-10].

The temperature distribution characteristics of the geothermal field is an important basis for establishing the genetic model for the Ruidian geothermal field. The calculation of the thermal reservoir temperature and the study of the hot fluid mixing mode provide important support for establishing the genetic model for the Ruidian geothermal field.

\section{GEOLOGICAL SETTING}

The Ruidian geothermal area is a remote area in the western part of Yunnan Province, close to the border with Myanmar (Figure 1A). It is situated on the east end of the Tibet-Yunnan geothermal zone and on the northern margin of the Tengchong volcanic area, which is part of the Tengchong block that developed along the eastern collision boundary between the Indian and Eurasian plates [11]. Being located $50 \mathrm{~km}$ north of Tengchong county, the main heat display area of the Ruidian geothermal field is in the Axin Street-Dagoubian zone (Figure 1B). There 39 hot springs have been discovered, many of which are spring clusters. The highest hot spring water temperature can reach $91.5^{\circ} \mathrm{C}$, which is the characteristic of the high-energy geothermal resources. 


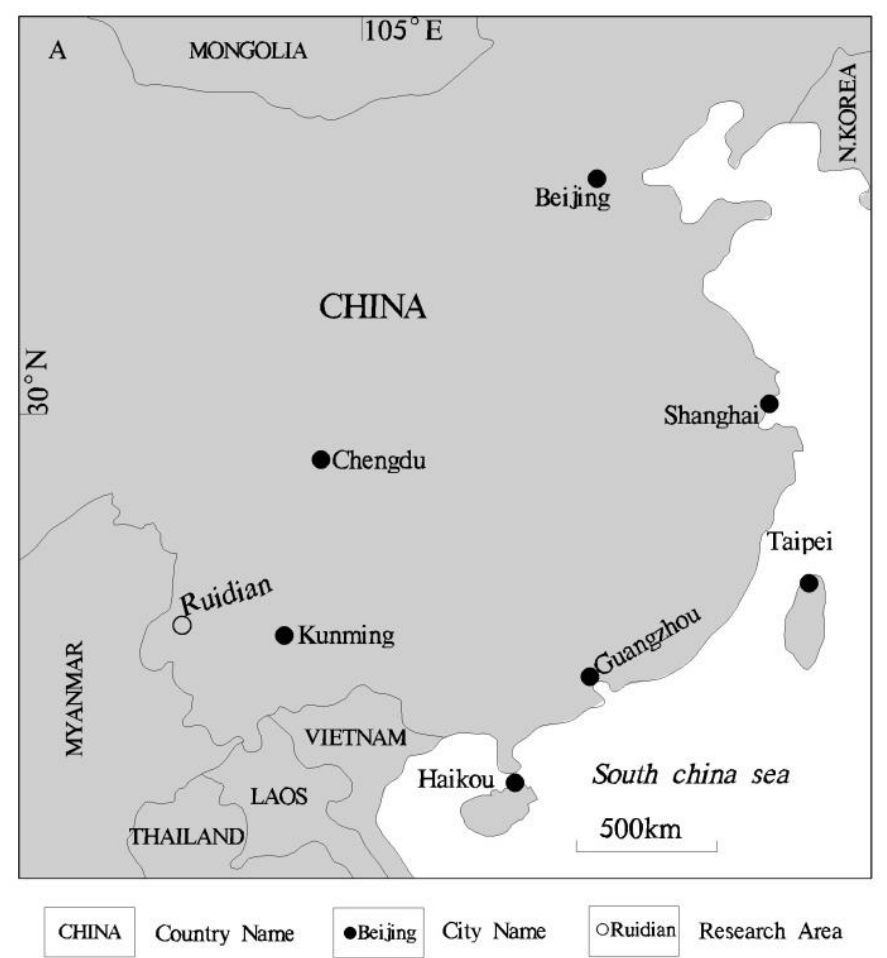

(a)

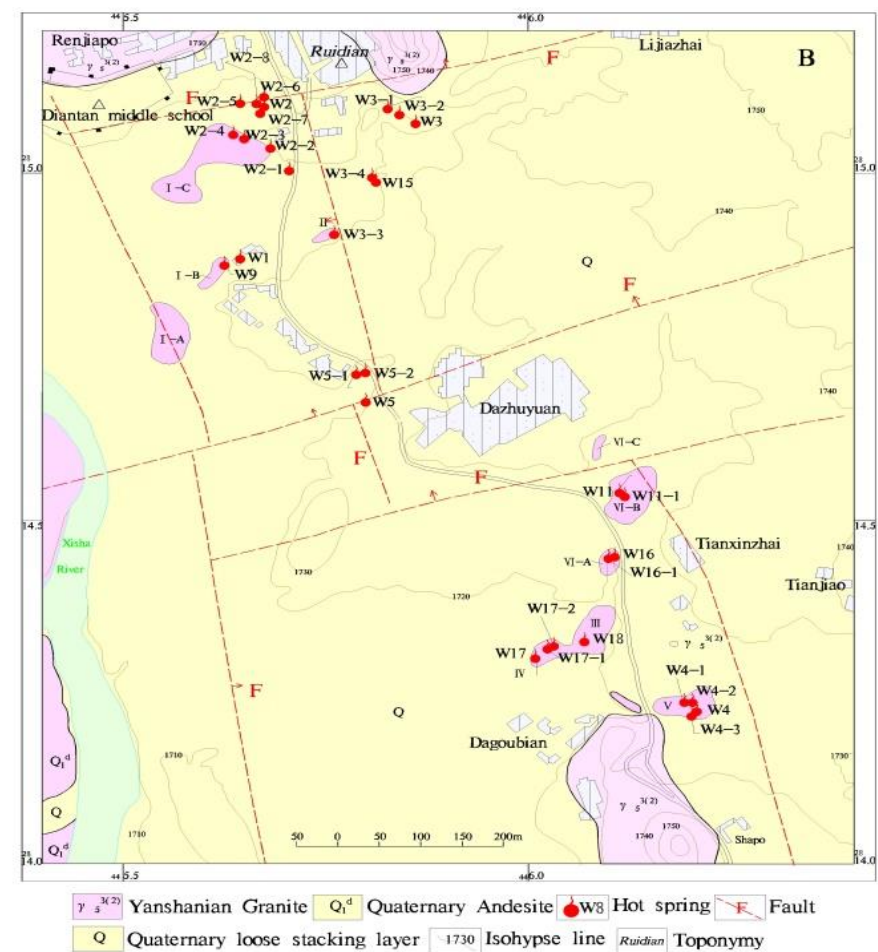

(b)

Figure 1. (A) Location of the Ruidian geothermal field. (B) Hydrogeological map of the Ruidian geothermal field.

The Ruidian geothermal field is located in the north of the Tengchong synclinorium in the Tengchong fold belt of Gaoligong Mountain. The Tengchong complex is composed of mixed lithologic rocks and granites, and the remaining Upper Paleozoic strata are distributed in intermediate-acidic composite intrusions. The meso-eruptive rocks and craters of the third and quaternary systems cover part of the south and north Tengchong. The study area is a north-south intermountain basin. The Xisha River runs from the north to the south and flows south into the Longchuan River. The stratigraphic distribution, tectonic lines and hydrothermal activities of the Ruiqi geothermal field are all controlled by the regional geological structure (Figure 1B). Until the early Cenozoic, this area experienced intense tectonic activities, forming numerous volcanoes and extensive faults [12].

The geothermal flow in the Tengchong-Ruidian area can reach up to $120.5 \mathrm{~mW} / \mathrm{m}^{2}$, which is about twice the global average $\left(61.6 \mathrm{~mW} / \mathrm{m}^{2}\right)$. Similar to the situation of geothermal heat distribution, the geothermal gradient in the Tengchong area averages $4.61^{\circ} \mathrm{C} / 100 \mathrm{~m}$, which is the highest value in the province [13]. The geothermal gradient of the borehole temperature measurement in the Ruidian geothermal field in the study area is relatively high, generally reaching $30^{\circ} \mathrm{C} / 100$ $\mathrm{m}$, with more significant geothermal anomaly.

Based on the systematic study of the geological structure characteristics, the Ruidian geothermal field can be divided into high-temperature thermal reservoirs in the deep granite weathering zone and thermal reservoirs in the lower pale gravel and pebble layers.

\section{TEMPERATURE CALCULATION OF SHALLOW GEOTHERMAL RESERVOIR}

The temperature of the geothermal reservoir is a key parameter to analyze the formation causes of geothermal systems and to evaluate the potential of the geothermal resources. In the literatures, numerical studies have been conducted to formulate, calibrate and improve the geochemical thermometric scale, including Eillis and Mahon's studies in 1964, 1966 and 1970; Trsdell and Fournier's in 1966, 1970, 1973, 1976 and 1977 and Arnorsson's in 1970, 1985 and 2000. More than a dozen of geothermometer models have been developed to study the temperature of the geothermal reservoir, e.g., $\mathrm{SiO}_{2}$, cationic, inert gas and isotope geothermometers [14-18].

The sampling was completed in 2016. During sampling, the water temperatures and $\mathrm{pH}$ values were measured on-site by portable measuring instruments; the water sample used for $\mathrm{SiO}_{2}$ determination was diluted 5 times immediately after being collected, and then stored in a $100 \mathrm{~mL}$ polyethylene bottle; the water samples used for other tests were put into 100 $\mathrm{mL}$ polyethylene bottles after the suspended substances were removed. The water samples must fill up the sampling bottles to prevent gas from entering. The hydrochemical characteristics of the hot spring samples in Ruidian are shown in Table 1.

Table 1. Chemical characteristics of water samples from hot springs in the Ruidian geothermal area

\begin{tabular}{c|c|c|c|c|c|c|c|c|c|c}
\hline Hot spring No. & $\mathrm{pH}$ & $\mathrm{T}\left({ }^{\circ} \mathrm{C}\right)$ & $\begin{array}{c}\mathrm{Ca}^{2+} \\
\mathrm{mg} / \mathrm{L}\end{array}$ & $\begin{array}{c}\mathrm{K}^{+} \\
\mathrm{mg} / \mathrm{L}\end{array}$ & $\begin{array}{c}\mathrm{Mg}^{2+} \\
\mathrm{mg} / \mathrm{L}\end{array}$ & $\begin{array}{c}\mathrm{Ca}^{2+} \\
\mathrm{mg} / \mathrm{L}\end{array}$ & $\begin{array}{c}\mathrm{Cl}^{-} \\
\mathrm{mg} / \mathrm{L}\end{array}$ & $\begin{array}{c}\mathrm{SO}_{4}^{2-} \\
\mathrm{mg} / \mathrm{L}\end{array}$ & $\begin{array}{c}\mathrm{HCO}_{3}^{-} \\
\mathrm{mg} / \mathrm{L}\end{array}$ & $\begin{array}{c}\mathrm{SiO}_{2} \\
\mathrm{mg} / \mathrm{L}\end{array}$ \\
\hline $\mathrm{W} 1$ & 7.3 & 91.5 & 400.0 & 37.0 & 3.6 & 26.8 & 153.1 & 18.0 & 948.4 & 134.0 \\
$\mathrm{~W} 2$ & 7.1 & 85.0 & 375.0 & 35.5 & 4.0 & 32.5 & 144.6 & 16.0 & 929.0 & 116.0 \\
$\mathrm{~W} 3$ & 6.8 & 75.0 & 325.0 & 31.5 & 3.1 & 23.8 & 128.9 & 15.0 & 790.8 & 108.0
\end{tabular}




\begin{tabular}{|c|c|c|c|c|c|c|c|c|c|c|}
\hline W4 & 6.9 & 74.0 & 340.0 & 30.0 & 3.8 & 28.6 & 138.9 & 16.0 & 799.7 & 130.0 \\
\hline W5 & 6.5 & 57.0 & 230.0 & 23.0 & 2.7 & 15.2 & 91.6 & 14.0 & 535.1 & 96.0 \\
\hline W9 & 7.2 & 72.0 & 375.0 & 37.5 & 3.9 & 24.9 & 151.2 & 24.0 & 911.5 & 130.0 \\
\hline W15 & 8.2 & 91.0 & 385.0 & 38.5 & 3.7 & 24.5 & 155.2 & 16.0 & 942.0 & 150.0 \\
\hline B-ZY1 & 7.4 & 87.0 & 387.0 & 40.0 & 3.5 & 24.6 & 158.6 & 17.0 & 935.0 & 145.0 \\
\hline B-LX & 7.0 & 75.6 & 345.0 & 33.8 & 3.5 & 21.8 & 132.7 & 24.0 & 780.3 & \\
\hline B-JZ & 7.0 & 77.0 & 378.0 & 35.4 & 3.8 & 25.7 & 159.3 & 22.0 & 819.7 & \\
\hline W16 & 7.2 & 53.0 & 290.5 & 44.0 & 8.4 & 6.3 & 147.6 & 30.0 & 559.6 & 120.0 \\
\hline W16-1 & 7.7 & 60.8 & 355.0 & 31.5 & 1.4 & 12.6 & 133.6 & 30.0 & 778.0 & 140.0 \\
\hline W17 & 7.3 & 58.5 & 350.0 & 31.5 & 2.1 & 16.1 & 144.9 & 20.0 & 766.6 & 125.0 \\
\hline ZK14 & 7.2 & 67.3 & 390.0 & 41.0 & 4.1 & 30.0 & 152.1 & 30.0 & 972.5 & 130.0 \\
\hline $\mathrm{T}-\mathrm{W} 1$ & 7.5 & 86.5 & 400.0 & 42.0 & 3.6 & 23.6 & 157.0 & 16.0 & 912.0 & 148.0 \\
\hline T-W2 & 7.5 & 87.0 & 410.0 & 45.0 & 4.2 & 4.5 & 140.0 & 31.2 & 895.0 & 129.0 \\
\hline T-W3 & 7.2 & 77.0 & 350.0 & 34.0 & 3.3 & 22.2 & 139.0 & 32.0 & 775.0 & 123.0 \\
\hline T-W4 & 7.5 & 81.0 & 400.0 & 36.0 & 3.7 & 23.6 & 164.0 & 24.0 & 837.0 & 140.0 \\
\hline T-W5 & 6.0 & 56.0 & 245.0 & 28.5 & 3.3 & 7.5 & 76.9 & 14.6 & 520.0 & 104.0 \\
\hline T-W17 & 8.1 & 64.0 & 378.0 & 36.6 & 2.5 & 7.5 & 133.0 & 25.0 & 768.0 & 126.0 \\
\hline Z-JM & 8.2 & 79.3 & 154.0 & 39.2 & 6.5 & 4.9 & 181.0 & 31.8 & 927.0 & 160.0 \\
\hline Z-GX & 8.5 & 74.9 & 165.0 & 42.9 & 6.3 & 4.9 & 200.0 & 34.5 & 939.0 & 180.0 \\
\hline G-XL & 7.6 & 90.0 & 326.0 & 30.8 & 2.0 & 15.5 & 130.9 & 27.3 & 928.0 & 251.8 \\
\hline G-JY & 7.0 & 86.0 & 290.1 & 29.2 & 2.0 & 20.4 & 117.6 & 25.2 & 906.2 & 222.6 \\
\hline G-XR & 7.5 & 75.0 & 250.2 & 26.6 & 1.7 & 17.7 & 105.0 & 25.5 & 752.7 & 197.1 \\
\hline G-ZY & 6.9 & 85.0 & 320.2 & 33.9 & 2.1 & 21.6 & 119.1 & 27.1 & 902.2 & 254.0 \\
\hline L-LX & 6.6 & 73.2 & 193.5 & 27.5 & 2.7 & 24.7 & 132.2 & 13.0 & 869.5 & \\
\hline L-XX & 7.8 & 68.7 & 272.8 & 34.6 & 2.3 & 12.5 & 108.7 & 13.8 & 880.3 & \\
\hline L-SP & 6.9 & 62.0 & 278.5 & 35.6 & 2.6 & 17.6 & 125.5 & 19.0 & 904.6 & \\
\hline L-ZY & 6.9 & 61.6 & 391.9 & 83.9 & 4.1 & 25.8 & 165.8 & 28.2 & 1016.0 & \\
\hline L-GX & 7.4 & 72.2 & 388.0 & 76.0 & 3.6 & 17.6 & 166.4 & 28.4 & 1012.9 & \\
\hline L-JZ & 6.6 & 80.0 & 372.1 & 75.1 & 3.6 & 28.0 & 156.1 & 26.8 & 991.6 & \\
\hline L-JM & 7.2 & 58.3 & 383.1 & 75.4 & 3.6 & 27.5 & 161.6 & 27.8 & 1006.8 & \\
\hline B-GX & 7.5 & 73.5 & 421.0 & 44.0 & 3.8 & 21.0 & 164.0 & 28.0 & 983.0 & 139.0 \\
\hline B-ZY & 6.8 & 82.1 & 390.0 & 43.0 & 4.0 & 25.0 & 154.0 & 27.0 & 938.0 & 128.0 \\
\hline
\end{tabular}

\subsection{Cationic geothermometer model}

The cationic geothermometer model is based on the relationship between the water temperature and the cation ratio per gram in the water, e.g., $\mathrm{Ca}^{2+}, \mathrm{Mg}^{2+}, \mathrm{K}^{+}, \mathrm{Na}^{+}, \mathrm{Li}^{+}$. Scholars have developed corresponding cationic geothermometer models to study different geothermal systems [19-21]. The water-rock interactions and mixed convection between waters should been taken into account in the analysis and evaluation on the results of the cationic geothermometer.

\section{2 $\mathrm{SiO}_{2}$ solubility geothermometer model}

The $\mathrm{SiO}_{2}$ solubility geothermometer model is based on the water temperature and the solubility of $\mathrm{SiO}_{2}$ in the water. It has been widely applied [22]. Arnorsson (1975, 1985 and 2000) pointed out the relationship between the temperature of the geothermal water and the $\mathrm{SiO}_{2}$ solubility. The latter is controlled by quartz, chalcedony and both of them when $T>180^{\circ} \mathrm{C}, T<110^{\circ} \mathrm{C}$ and $110^{\circ} \mathrm{C}<T<180^{\circ} \mathrm{C}$, respectively.

\subsection{Geothermometer model application condition: Water- rock interaction equilibrium}

\subsubsection{Log $(\mathrm{Q} / \mathrm{K})-\mathrm{T}$ curve analysis}

The mineral saturation index $(\log (\mathrm{Q} / \mathrm{K}))$ is used to estimate the solubility equilibrium of minerals in the water, where $\mathrm{Q}$ is the active product and $\mathrm{K}$ is the theoretical equilibrium constant. This paper uses the software Phreeqci to produce the log $(\mathrm{Q} / \mathrm{K})-\mathrm{T}$ curves of anhydrite, aragonite, calcite, chalcedony, chrysotile, domolite, gypsum, quartz and sepiolite in the samples of hot spring W3, as shown in Table 2 and Figure 2.

Table 2. Mineral saturation indices of the water samples from the hot spring in the study area

\begin{tabular}{cccccccccccc}
\hline \multirow{2}{*}{ Number } & Anhydrite & $\begin{array}{c}\text { Ara } \\
\text { gonite }\end{array}$ & Calcite & $\begin{array}{c}\text { Chalce } \\
\text { dony }\end{array}$ & $\begin{array}{c}\text { Chry } \\
\text { sotile }\end{array}$ & $\begin{array}{c}\text { Domo } \\
\text { lite }\end{array}$ & Gypsum & Halite & Quartz & $\begin{array}{c}\text { Sepio } \\
\text { lite }\end{array}$ & Talc \\
\hline W1 & -2.48 & 0.81 & 0.92 & -0.07 & -0.21 & 1.27 & -2.85 & -5.98 & 0.19 & -2.51 & 4.02 \\
W2 & -2.53 & 0.62 & 0.73 & -0.07 & -2.02 & 0.92 & -2.81 & -6.02 & 0.20 & -3.56 & 2.15 \\
W3 & -2.78 & 0.11 & 0.22 & -0.02 & -4.63 & 0.00 & -2.95 & -6.10 & 0.27 & -4.94 & -0.44 \\
W4 & -1.86 & 1.23 & 1.34 & 0.07 & -3.98 & 1.20 & -2.02 & -6.08 & 0.17 & -4.33 & 0.38 \\
W5 & -3.13 & -0.79 & -0.67 & 0.09 & -8.72 & -1.56 & -3.12 & -6.34 & 0.23 & -6.95 & -4.47 \\
W9 & -2.65 & 0.51 & 0.62 & 0.08 & -2.11 & 0.92 & -2.79 & -5.97 & 0.19 & -3.00 & 2.27 \\
W15 & -2.77 & 1.42 & 1.53 & -0.06 & 5.16 & 2.70 & -3.13 & -6.00 & 0.10 & 1.09 & 9.40 \\
W16 & -3.28 & -0.50 & -0.38 & 0.22 & -3.10 & -0.10 & -3.24 & -6.04 & 0.27 & -2.86 & 1.38 \\
W16-1 & -2.96 & 0.45 & 0.57 & 0.21 & -1.81 & 0.71 & -2.99 & -6.02 & 0.24 & -2.26 & 2.72 \\
W17 & -3.03 & 0.19 & 0.32 & 0.19 & -3.66 & 0.28 & -3.03 & -5.98 & 0.22 & -3.46 & 0.80 \\
\hline
\end{tabular}




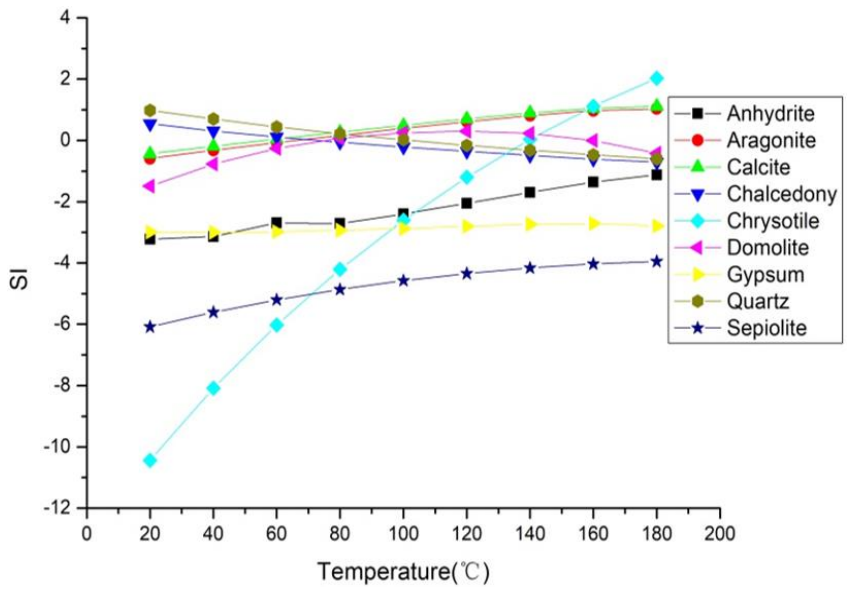

Figure 2. $\log (\mathrm{Q} / \mathrm{K})$ - $\mathrm{T}$ curves of the mineral solubility equilibrium in hot spring W3

From Figure 2, it is found that the minerals cannot be saturated simultaneously at a certain temperature. This indicates that the hot spring water may mix with cold water when rising and being exposed. Therefore, it is difficult to estimate the precise equilibrium temperature of the hot spring and the mineral solubility equilibrium.

\subsubsection{Na-K-Mg triangle diagram analysis}

First, the author used Giggenbach's $\mathrm{Na}-\mathrm{K}-\mathrm{Mg}$ triangle diagram to investigate the source of the water, and evaluate the equilibrium of water-rock interactions. Based on this, the author could analyze whether the cationic geothermometer model could be used to calculate the temperature of geothermal fields [23].

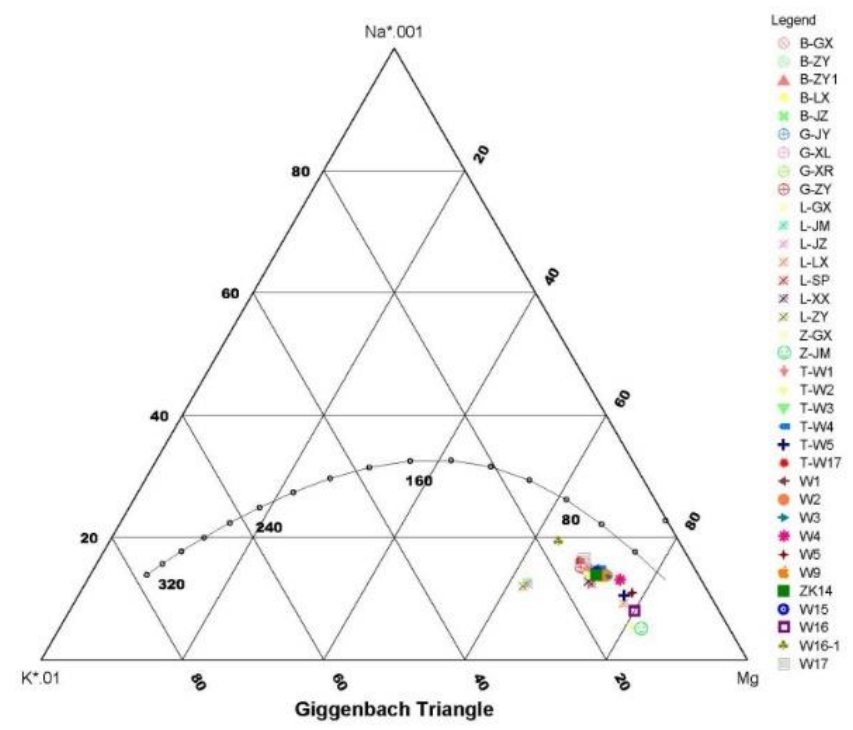

Figure 3. $\mathrm{Na}-\mathrm{K}-\mathrm{Mg}$ triangle diagram of the Ruidian hot springs

Second, this paper used the software Aquachem to produce the Na-K-Mg triangle diagram of the Ruidian hot springs, as shown in Figure 3. It is found that all the hot springs in Ruidian are not mineral-saturated. The estimation results of the cationic geothermometer model will be negatively biased due to the disequilibrium of mineral solubility and the mix with cold water. Therefore, the cationic geothermometer model is not suitable in this case, and the temperature estimated by this model can only be used as reference.

\subsection{3 $\mathrm{SiO}_{2}$ Solubility Curve Analysis}

The concentration of $\mathrm{SiO}_{2}\left(\rho\left(\mathrm{SiO}_{2}\right)\right.$, with a unit of $\left.\mathrm{mg} \mathrm{L}^{-1}\right)$ in samples are between the curves of chalcedony and amorphous silicon dioxide, as shown in Figure 4. It can be found that the amorphous silicon dioxide shows dissolution disequilibrium while chalcedony and quartz may control the $\mathrm{SiO}_{2}$ dissolution equilibrium. Therefore, chalcedony and quartz geothermometers are more suitable in estimating the temperature of shallow geothermal reservoirs.

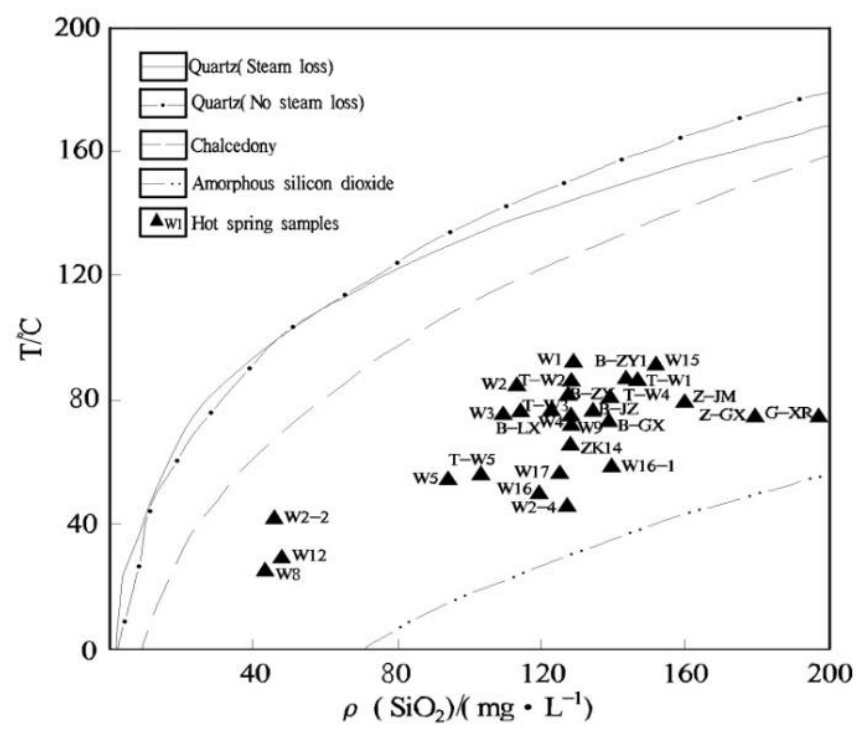

Figure 4. $\mathrm{T}-\rho\left(\mathrm{SiO}_{2}\right)$ curves of the hot springs in Ruidian area

\subsection{Geothermometer calculation of ruidian geothermal fields}

After studying the cationic geothermometer model and the $\mathrm{SiO}_{2}$ solubility geothermometer model, the author used the $\mathrm{Na}-\mathrm{K}$ geothermometer and the $\mathrm{K}-\mathrm{Mg}$ geothermometer at a temperature of $206-221^{\circ} \mathrm{C}$ and of $105-124^{\circ} \mathrm{C}$, respectively. Due to the dissolution disequilibrium of ions, the results from the Na-K geothermometer were higher than the actual values. Then it was used to calculate the temperature of the deep reservoir. However, the limitation of the $\mathrm{Mg}$ concentration resulted in lower results than actual values when the $\mathrm{K}-\mathrm{Mg}$ geothermometer was applied. Therefore, it is not suitable to use the $\mathrm{K}-\mathrm{Mg}$ geothermometer to calculate the temperature of a high-temperature geothermal field.

According to the above analysis and mineral saturation indices, it is believed that the quartz geothermometer is a conservative method to estimate the temperature of a shallow reservoir. The results from the quartz geothermometer were around $145^{\circ} \mathrm{C}$, which can be used as reference data for the shallow reservoir of the Ruidian hot springs. The calculated temperatures by different geothermometers are listed in Table 3 . 
Table 3. Calculated temperatures from different geothermometer models $\left({ }^{\circ} \mathrm{C}\right)$

\begin{tabular}{ccccccc}
\hline \multirow{2}{*}{ Number } & $\begin{array}{c}\text { T (Hot } \\
\text { spring) }\end{array}$ & $\begin{array}{c}\text { T-K-Mg } \\
\text { (Giggenbach, 1986) }\end{array}$ & $\begin{array}{c}\text { T-Na-K-Ca (Fournier and } \\
\text { Tracsdell, 1973) }\end{array}$ & $\begin{array}{c}\text { T-Na-K } \\
\text { (Fournier, 1983) }\end{array}$ & $\begin{array}{c}\text { T-SiO } 2 \\
\text { (Arnorsson, 1985) }\end{array}$ & $\begin{array}{c}\text { T-SiO } 2 \\
\text { (Arnorsson, 2000) }\end{array}$ \\
\hline W1 & 91.5 & 114.6 & 168.0 & 210.3 & 154.2 & 154.5 \\
W2 & 85.0 & 112.0 & 158.4 & 212.3 & 145.6 & 145.8 \\
W3 & 75.0 & 112.3 & 160.3 & 214.3 & 141.5 & 141.7 \\
W4 & 74.0 & 107.8 & 152.7 & 206.4 & 152.3 & 132.6 \\
W5 & 57.0 & 105.1 & 154.0 & 216.9 & 134.9 & 135.1 \\
W9 & 72.0 & 113.8 & 170.1 & 221.3 & 152.3 & 152.6 \\
ZK14 & 67.3 & 115.9 & 169.0 & 216.9 & 161.1 & 152.6 \\
W15 & 91.0 & 115.5 & 172.5 & 206.9 & 156.8 & 161.5 \\
W16-1 & 60.8 & 124.5 & 184.2 & 208.1 & 150.0 & 157.2 \\
W17 & 58.5 & 117.8 & 174.9 & & & 150.3 \\
\hline
\end{tabular}

\section{TEMPERATURE CALCULATION OF THE DEEP GEOTHERMAL RESERVOIR}

\subsection{Sign of hot spring water mixed with cold water}

For a high temperature hot spring, $\mathrm{Cl}^{-}$is a reference ion, which can be used to indicate the mixing process of hot spring water and cold water, and also to identify the impacts of other processes on other ions. In the mixing process of the hot spring water with cold water in Ruidian, the concentration of $\mathrm{Cl}^{-}$is in good linear relationships with the concentrations of other ions. Such linear relationships can be analyzed together with the water-rock interactions to find out the impacts of cold water in the mixing process.

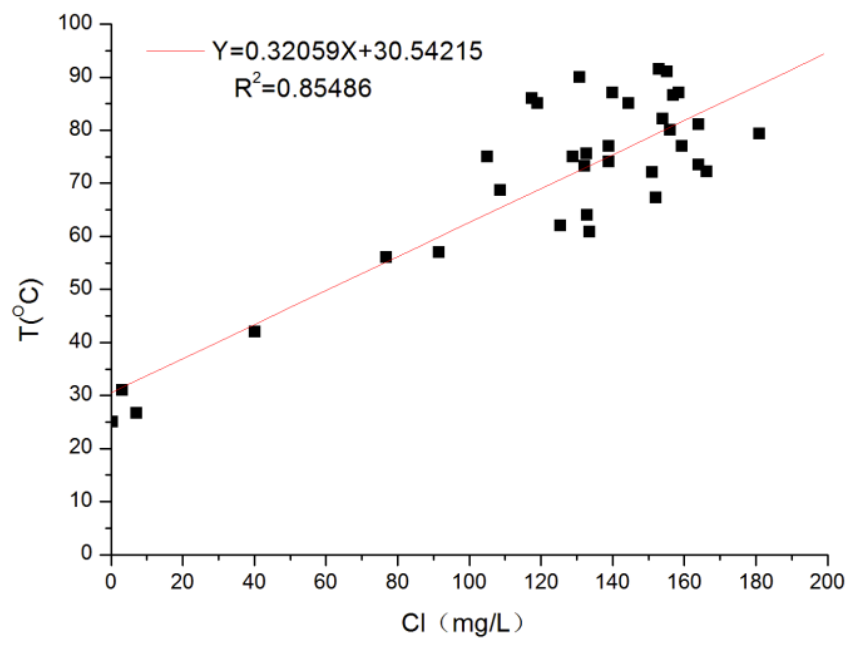

Figure 5. Temperature- $\mathrm{Cl}^{-}$concentration curve of the exposed hot springs in Ruidian area

The concentration of $\mathrm{Cl}^{-}$is positively correlated with the temperature of the hot spring, with a correlation coefficient $\left(\mathrm{R}^{2}\right)$ of 0.85486, as shown in Figure 5. This correlation also reflects that the hot spring water is mixed with cold water in the rising process.

\subsection{Temperature calculation of the geothermal reservoir}

\subsubsection{Dissolved silica- enthalpy plot}

The dissolved silica-enthalpy plot was first proposed by R.O. Fournier and A.H. Truesdell [24]. In this paper, the author chose some sampling spots and prepared the dissolved silica-enthalpy plot to determine the mix proportion of cold water and the possible hot spring temperature. The process of preparing the dissolved silica-enthalpy plot of the Ruidian geothermal field is shown as follows:

(1) Ambient temperature: $\mathrm{T}_{0}=15^{\circ} \mathrm{C}$. The cold water at this temperature did not mix with the hot spring water. The $\mathrm{SiO}_{2}$ concentration was $16.2 \mathrm{ppm}$ (which is the average concentration of $\mathrm{SiO}_{2}$ in the water with the temperature ranging between $14-16^{\circ} \mathrm{C}$ ). This was marked as point $\mathrm{A}$ in Figure 6.

(2) Different hot spring temperatures and the corresponding $\mathrm{SiO}_{2}$ concentrations were marked as point $\mathrm{B}$ in Figure 6.

(3) The $\mathrm{AB}$ extension line and the quartz solubility curve cross at point $\mathrm{C}$. From this point, the enthalpy of water in the deep geothermal reservoir can be obtained.

(4) The line length ratio of $\mathrm{BC} / \mathrm{AC}$ can be used to calculate the cold water proportion. The concentrations of $\mathrm{SiO}_{2}$ dissolved in the hot spring water and the water temperatures (listed in Table 1) constitute the dissolved silica-enthalpy plot (Figure 6). According to this figure, the cold water proportion and the enthalpy of the hot fluid can be obtained. The calculated temperatures of the thermal reservoir are shown in Table 4

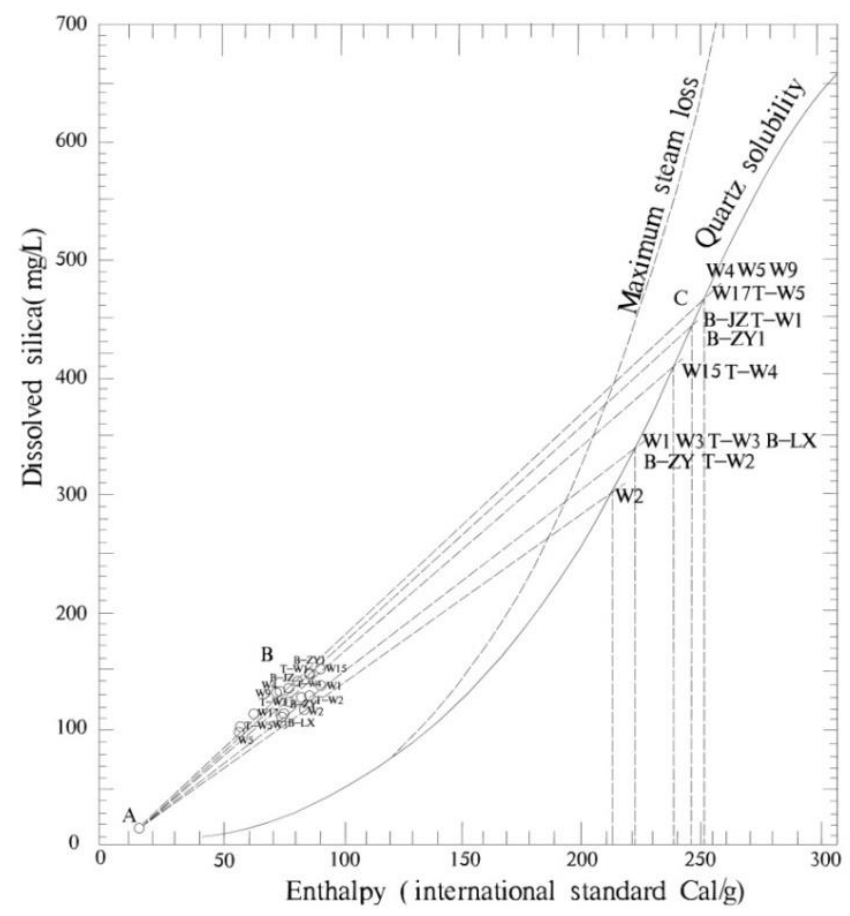

Figure 6. Dissolved silica-enthalpy plot of the Ruidian hot spring (based on Fournier and Truesdell's) 
Table 4. Results of the dissolved silica-enthalpy plot of the Ruidian hot spring

\begin{tabular}{cccc}
\hline $\begin{array}{c}\text { Hot } \\
\text { spring } \\
\text { number }\end{array}$ & $\begin{array}{c}\text { Cold water } \\
\text { proportion } \\
(\%)\end{array}$ & $\begin{array}{c}\text { The Enthalpy } \\
\text { of the deep } \\
\text { hot fluid } \\
\text { (Cal/g) }\end{array}$ & $\begin{array}{c}\text { Thermal } \\
\text { reservoir } \\
\text { temperature } \\
\left({ }^{\circ} \mathbf{C}\right)\end{array}$ \\
\hline W1 & 63 & 226 & 220 \\
W2 & 65 & 214 & 210 \\
W3 & 71 & 223 & 218 \\
W4 & 75 & 257 & 248 \\
W5 & 82 & 257 & 248 \\
\hline
\end{tabular}

\subsubsection{Dissolved chloride-enthalpy plot}

The dissolved chloride-enthalpy plot was first proposed by Fournier in 1979. It can not only describe the cooling processes during rising of the hot fluid, but also calculate the temperature of the geothermal fluid (i.e., the initial geothermal fluid in the Ruidian high-temperature geothermal field), which cannot be calculated by any other chemical geothermometer [25].

First, the ambient temperature $\mathrm{T}_{0}=15^{\circ} \mathrm{C}$. This was the temperature, at which the cold water did not mix with the hot spring water. The $\mathrm{Cl}^{-}$concentration was $2.09 \mathrm{mg} / \mathrm{L}$ in this cold water (which is the average concentration of $\mathrm{Cl}^{-}$in the water at a temperature ranging between $14-16^{\circ} \mathrm{C}$ ). The author drew the mixed line in the dissolved chloride-enthalpy plot (Figure 7). The mixed line crossed with the steam loss line at a point. The $\mathrm{x}$-coordinate and $\mathrm{y}$-coordinate were the $\mathrm{Cl}^{-}$concentration and the enthalpy of the initial geothermal fluid, $883 \mathrm{~J} / \mathrm{g}$. According to the saturated water enthalpy-temperature datasheet, the temperature of the initial geothermal fluid was approximately $217^{\circ} \mathrm{C}$.

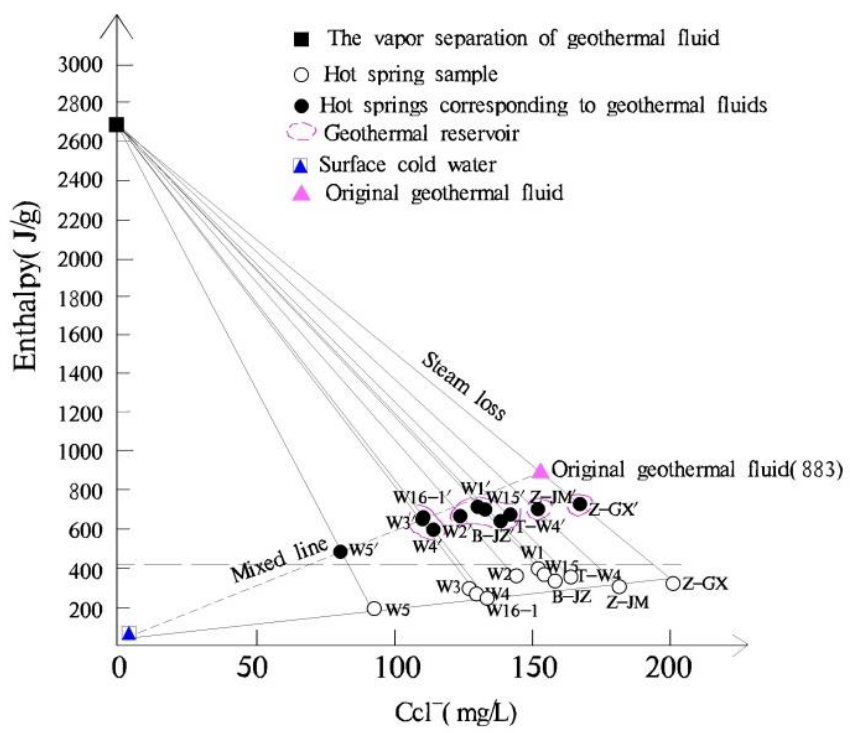

Figure 7. Dissolved chloride-enthalpy plot of Ruidian hot springs (according to nicholson, fournier)

4.2.3 Geothermometer scale plot to calculate the cold water proportion

Considering the mixing with cold water, the $\mathrm{SiO}_{2}$ (Quartz or Chalcedony) solubility geothermometer model can be applied to calculate the thermal reservoir temperature after the mixing process. In the literatures, some scholars argued that the mixing process had little impact on the $\mathrm{Na} / \mathrm{K}$ ratio, and that the $\mathrm{Na} / \mathrm{K}$ geothermometer model can also be used in such cases [18-20].

The author applied an integrated plot to calculate the temperature of the hot fluid and the mix proportion of the cold water. Take the spot W2 in Ruidian area for example. The temperature of the exposed water was $85^{\circ} \mathrm{C}$, and the concentrations of $\mathrm{Na}+$ and $\mathrm{K}+$ were 375 and $35 \mathrm{mg} / \mathrm{L}$, respectively. Based on the data, the author calculated the $\mathrm{Na} / \mathrm{K}$ geothermometer scale to be $211.1^{\circ} \mathrm{C}$, and $\mathrm{SiO}_{2}$ solubility geothermometer scale to be $145.7^{\circ} \mathrm{C}$. The ambient temperature was $15^{\circ} \mathrm{C}$, and the average concentrations of $\mathrm{Na}+, \mathrm{K}+$ and $\mathrm{SiO}_{2}$ were 3.58, 2.56 and $16.2 \mathrm{mg} / \mathrm{L}$, respectively. Suppose the cold water at $15^{\circ} \mathrm{C}$ was mixed with the hot fluid, the $\mathrm{Na}+$ and $\mathrm{K}+$ concentrations in the hot fluid before the mixing process can be calculated by following equations:

$$
\begin{aligned}
& \mathrm{Na}_{\mathrm{h}}=\frac{\mathrm{Na}_{\mathrm{m}}-\mathrm{Na}_{\mathrm{c}} x}{1-x} \\
& \mathrm{~K}_{\mathrm{h}}=\frac{\mathrm{K}_{\mathrm{m}}-\mathrm{K}_{\mathrm{c}} X}{1-X}
\end{aligned}
$$

where $\mathrm{Na}_{\mathrm{h}}, \mathrm{Na}_{\mathrm{m}}$ and $\mathrm{Na}_{\mathrm{c}}$ are the $\mathrm{Na}^{+}$concentrations in the hot fluid, the mixed water and the cold water, respectively. $K_{h}, K_{m}$ and $\mathrm{K}_{\mathrm{c}}$ are the $\mathrm{K}^{+}$concentrations in the hot fluid, the mixed water and the cold water, respectively. $X$ is the cold water proportion. Equations (1)/(2) gives the $\mathrm{Na} / \mathrm{K}$ ratio before the mixing. This ratio can be used to calculate the standard $\mathrm{Na} / \mathrm{K}$ geothermometer scale, shown as the line $\mathrm{AB}$ in Figure 8 . The $\mathrm{SiO}_{2}$ concentration in the hot fluid before the mixing can also be calculated in the same way.

Line $C D$ and line $A B$ cross at point $O$. From this point, it was calculated that the mixture of cold water was approximately $64 \%$. Line $\mathrm{MN}$ showed the temperature drop during the mixing process, in which temperatures of $\mathrm{M}$ and $\mathrm{N}$ were 208 and $15^{\circ} \mathrm{C}$, respectively. Line $\mathrm{MN}$ crosses with line $\mathrm{OE}$ at point $\mathrm{P}$. The $\mathrm{Y}$-coordinate of $\mathrm{P}$ is the temperature of the hot spring W2 $-86^{\circ} \mathrm{C}$, which is very close to the real temperature of the spot $\mathrm{W} 2$.

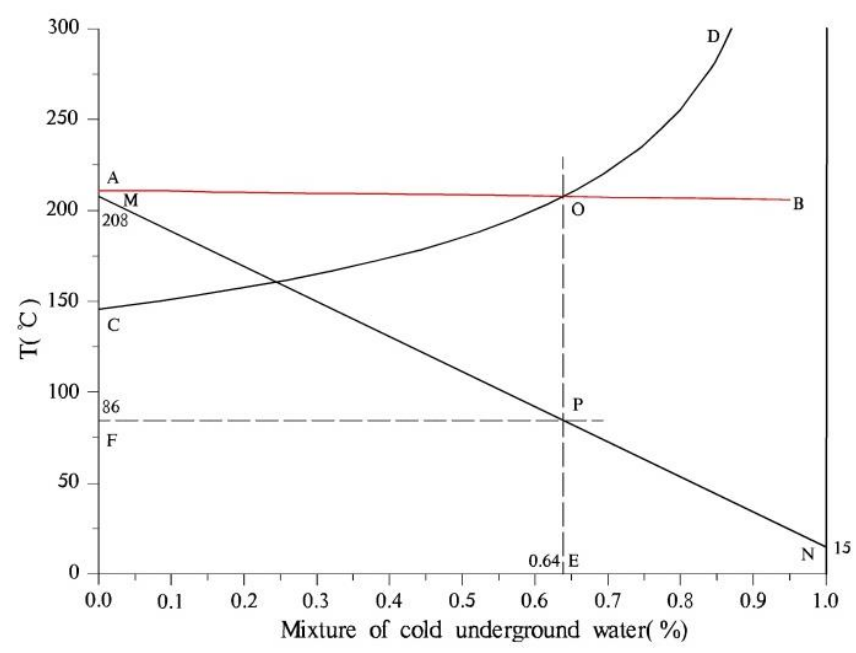

Figure 8. Geothermometer scale plot to calculate the cold water proportion in W2 (according to Tongwei)

\subsubsection{Linear regression equations iteration solution}

From the above models and calculations, the temperatures of the initial hot fluids, the concentrations of mineral ions and the proportions of cold water in different hot springs can be 
estimated. The hot springs in Ruidian are the mixture of the initial hot fluid and the underground cold water and then exposed to the ground. Thus, the author sampled from various hot spring spots and conducted the regression statistical analysis. The linear recursive analysis was performed on the

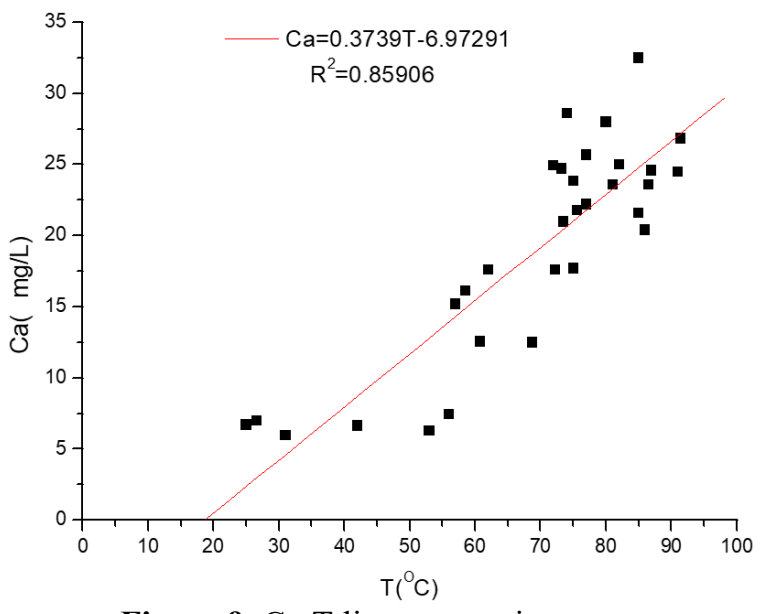

Figure 9. Ca-T linear recursive curve

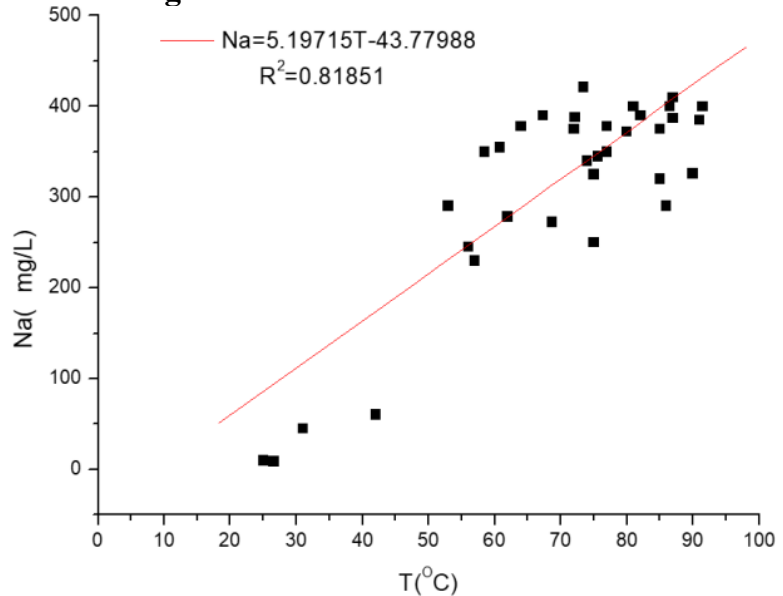

Figure 11. Na-T linear recursive curve

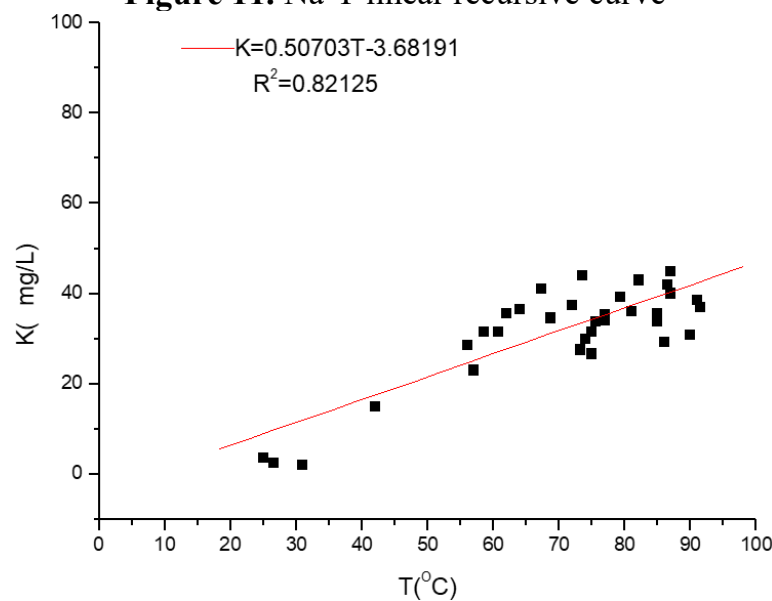

Figure 13. K-T linear recursive curve temperature (T) with concentrations of $\mathrm{K}^{+}, \mathrm{Na}^{+}, \mathrm{Ca}^{2+}, \mathrm{Mg}^{2+}$, $\mathrm{Cl}^{-}, \mathrm{SiO}_{2}, \mathrm{HCO}_{3}{ }^{-}, \mathrm{HBO}_{2}{ }^{-}, \mathrm{F}^{-}$and TDS in Origin 9.0. Part of the linear recursive curves are shown in Figures 9-14 and the calculation results listed in Table 5 .

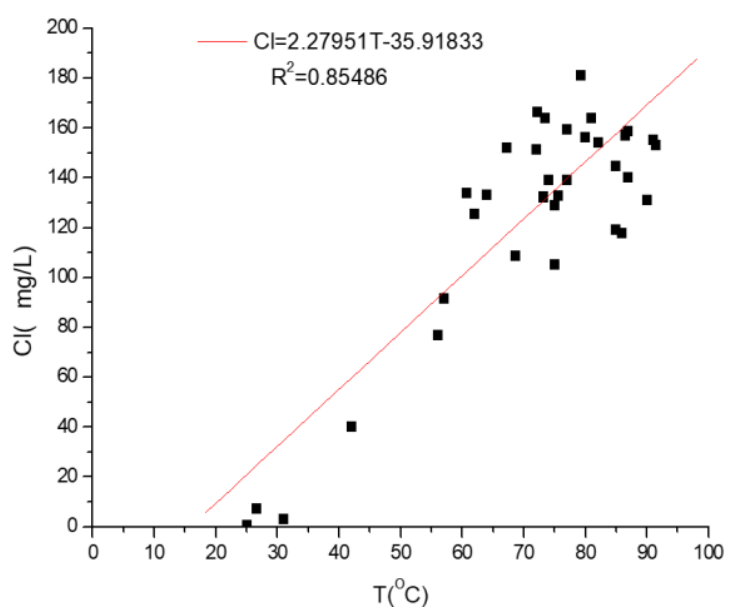

Figure 10. Cl-T linear recursive curve

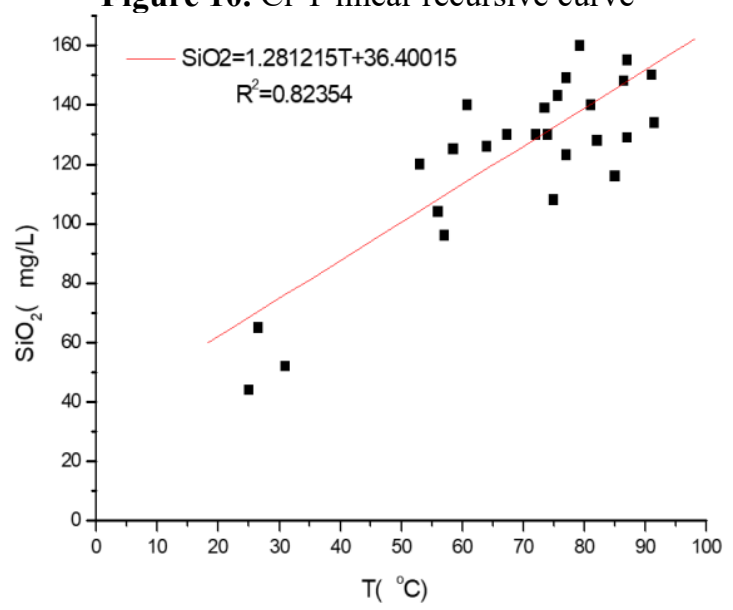

Figure 12. $\mathrm{SiO}_{2}-\mathrm{T}$ linear recursive curve

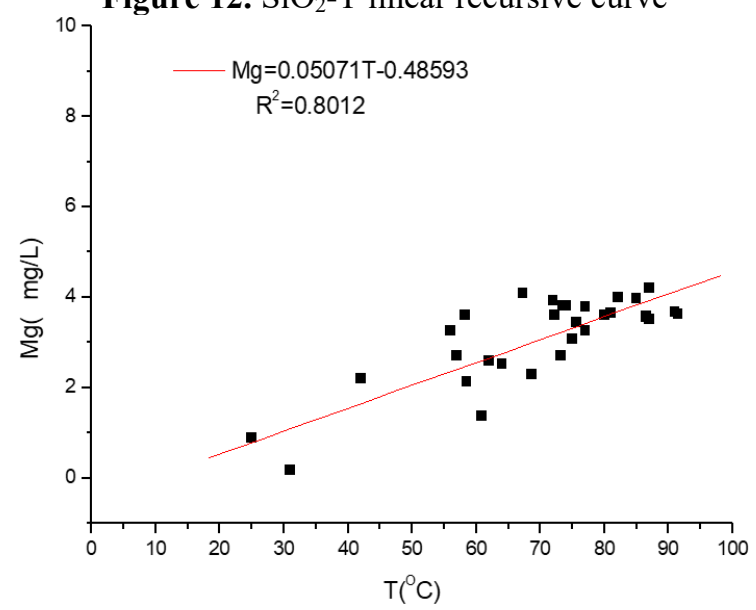

Figure 14. Mg-T linear recursive curve 
Table 5. Ion-temperature linear relationship statistics in Ruidian hot springs

\begin{tabular}{cccc}
\hline Ions & Coefficient & Regression equation & Equation number \\
\hline $\mathrm{Cl}-\mathrm{T}$ & 0.85486 & $\mathrm{Cl}=2.27951 \mathrm{~T}-35.91833$ & $(3)$ \\
$\mathrm{Na}-\mathrm{T}$ & 0.81851 & $\mathrm{Na}=5.19715 \mathrm{~T}-43.77988$ & $(4)$ \\
$\mathrm{Mg}-\mathrm{T}$ & 0.80120 & $\mathrm{Mg}=0.05071 \mathrm{~T}-0.48593$ & $(5)$ \\
$\mathrm{K}-\mathrm{T}$ & 0.82125 & $\mathrm{~K}=0.50703 \mathrm{~T}-3.68191$ & $(6)$ \\
$\mathrm{Ca}-\mathrm{T}$ & 0.85906 & $\mathrm{Ca}=0.3739 \mathrm{~T}-6.97291$ & $(7)$ \\
$\mathrm{HCO}-\mathrm{T}$ & 0.87803 & $\mathrm{HCO}_{3}=13.70012 \mathrm{~T}-184.5894$ & $(8)$ \\
$\mathrm{SiO}_{2}-\mathrm{T}$ & 0.82354 & $\mathrm{SiO}_{2}=1.281215 \mathrm{~T}+36.40015$ & $(9)$ \\
\hline
\end{tabular}

According to Fournier's research in 1981, when $\mathrm{SiO}_{2}$ achieves dissolution equilibrium, the solubility of $\mathrm{SiO}_{2}$ in water has the following relationship with temperature $\mathrm{T}$ :

$\mathrm{T}=1309 /\left(5.19-\log \mathrm{SiO}_{2}\right)-273.15$

Equation (10) is applicable to the conditions with no mixing of underground cold water. If the cold water proportion is 0 , Equation (9) becomes (10). Based on Equations (9) and (10), the author calculated the temperature of the initial hot fluid and the concentration of $\mathrm{SiO}_{2}$ :

$\mathrm{T}=211^{\circ} \mathrm{C} ; \mathrm{SiO}_{2}=306 \mathrm{mg} / \mathrm{L}$

This temperature $\left(211^{\circ} \mathrm{C}\right)$ is very close to the calculated value from the dissolved chloride-enthalpy plot $\left(217^{\circ} \mathrm{C}\right)$ and the dissolved silica-enthalpy plot $\left(220^{\circ} \mathrm{C}\right)(\mathrm{Eq} .11)$. Therefore, the linear regression equations iteration solution is also accurate and practicable. Substitute $\mathrm{T}=211^{\circ} \mathrm{C}$ into Equations (2)-(10), and the concentrations of other six ions are $\mathrm{Na}^{+}=1052.82, \quad \mathrm{~K}^{+}=103.30, \quad \mathrm{Ca}^{2+}=71.92, \quad \mathrm{Mg}^{2+}=10.21$, $\mathrm{Cl}^{-}=445.06$ and $\mathrm{HCO}_{3}{ }^{-}=2706.14 \mathrm{mg} / \mathrm{L}$, respectively.

The above values are the ion concentrations in hot springs. Based on the ion concentrations in cold water before mixing with the hot fluid (average concentration in the range of 14$16^{\circ} \mathrm{C}$ ), the cold water proportion in the mixed water are calculated in Table 6. According to this table, the cold water proportions in the exposed Ruidian hot springs are between $66 \%$ and $70 \%$, which are close to the values calculated in the Section 4.2. This demonstrates the practicability of the linear regression equations iteration solution. Through the study in this paper, it is estimated that the reasonable temperature of the deep geothermal reservoir is $220^{\circ} \mathrm{C}$.

Table 6. Cold water proportions in the mixed water in Ruidian area

\begin{tabular}{|c|c|c|c|c|c|c|c|c|c|c|c|c|c|c|}
\hline \multirow{2}{*}{ Ions } & \multicolumn{2}{|c|}{ Concentration $(\mathrm{mg} / \mathrm{L})$} & \multicolumn{12}{|c|}{ Cold water proportion in the mixed water $(\%)$} \\
\hline & Hot spring & Cold water & W1 & W2 & W3 & W4 & W5 & W9 & W15 & W16-1 & W17 & B-ZY1 & B-LX & B-JZ \\
\hline $\mathrm{K}^{+}$ & 103.3 & 2.56 & 0.66 & 0.67 & 0.71 & 0.73 & 0.80 & 0.65 & 0.64 & 0.71 & 0.71 & 0.63 & 0.69 & 0.67 \\
\hline $\mathrm{Na}^{+}$ & 1052.8 & 3.58 & 0.62 & 0.65 & 0.69 & 0.68 & 0.78 & 0.65 & 0.64 & 0.67 & 0.67 & 0.63 & 0.67 & 0.64 \\
\hline $\mathrm{Ca}^{2+}$ & 71.9 & 9.13 & 0.72 & 0.63 & 0.77 & 0.69 & 0.90 & 0.75 & 0.76 & 0.95 & 0.89 & 0.75 & 0.80 & 0.74 \\
\hline $\mathrm{Mg}^{2+}$ & 10.2 & 1.59 & 0.76 & 0.72 & 0.83 & 0.74 & 0.87 & 0.73 & 0.76 & 0.68 & 0.94 & 0.78 & 0.78 & 0.75 \\
\hline $\mathrm{Cl}^{-}$ & 445.1 & 2.10 & 0.66 & 0.68 & 0.71 & 0.69 & 0.80 & 0.66 & 0.65 & 0.70 & 0.68 & 0.65 & 0.71 & 0.65 \\
\hline $\mathrm{SiO}_{2}$ & 306.0 & 16.20 & 0.59 & 0.66 & 0.68 & 0.61 & 0.72 & 0.61 & 0.54 & 0.57 & 0.62 & 0.52 & 0.56 & 0.54 \\
\hline $\mathrm{HCO}_{3}{ }^{-}$ & 2706.1 & 7.35 & 0.65 & 0.66 & 0.71 & 0.71 & 0.80 & 0.66 & 0.65 & 0.71 & 0.72 & 0.66 & 0.71 & 0.70 \\
\hline \multicolumn{3}{|c|}{ Average } & 0.67 & 0.67 & 0.73 & 0.70 & 0.81 & 0.67 & 0.66 & 0.71 & 0.73 & 0.66 & 0.70 & 0.67 \\
\hline
\end{tabular}

\section{CONCLUSIONS}

1. The Na-K-Mg triangle diagram and the $\mathrm{SiO}_{2}$ solubility curves indicate that the cation reaction in the hot water system is not balanced. It is affected by the mixing of cold water. Estimation of the hot spring water temperature in the study area by the cation temperature scale method will result in a lower temperature value, hence the estimation results obtained by the cationic geothermometer model method can only be used as references.

2. By analyzing the use conditions of different temperature scale methods, based on the results of the fluid mineral saturation index, this paper finds it feasible to use the quartz temperature scale as a more conservative method to estimate the temperature of the thermal reservoir in the study area. The calculation results obtained by the quartz temperature scale method are mainly concentrated at about $145^{\circ} \mathrm{C}$, which can be used as a reference range for the temperature distribution of the shallow thermal reservoir in the geothermal field in the study area.
3. By using the dissolved silica-enthalpy plot method, silicon enthalpy equation method, dissolved chloride-enthalpy plot method and linear regression equations iteration solution, etc., this paper calculates the temperature of the deep thermal reservoir of the Ruidian geothermal field, which is around $220^{\circ} \mathrm{C}$, and also the mix proportion of the cold water, which is generally between $60 \%$ and $70 \%$.

\section{ACKNOWLEDGMENT}

This work was supported by the National Natural Science Foundation of China (No. 41502342) and the Geological survey project of China (No. DD20160303).

\section{REFERENCES}

[1] Guo QH. (2012). Hydrogeochemistry of hightemperature geothermal systems in China: A review. 
Applied Geochemistry 27(10): 1887-1898. http://dx.doi.org/10.1016/j.apgeochem.2012.07.006

[2] Wang GL, Zhang FW, Liu ZM. (2000). An analysis of present situation and prospects of geothermal energy development and utilization in the world. Acta Geoscientia Sinica (2): 134-139. http://dx.doi.org/10.3321/j.issn: 1006-3021.2000.02.004

[3] Ba JJ, Su CT, Li YQ. (2018). A case study on heat source mechanism of high-temperature geothermal field. Annales de Chimie - Science des Matériaux 42(1): 129147. http://dx.doi.org/10.3166/ACSM.42.129-147

[4] Moraci F, Fazia C, Errigo MF. (2018). Smart tools for energy resilient city. Annales de Chimie - Science des Matériaux 42(4): 459-470. http://dx.doi.org/10.3166/ACSM.42.459-470

[5] Mongillo MA. (2010). Preface to geothermics special issue on sustainable geothermal utilization. Geothermics 39(4): 279-282. http://dx.doi.org/10.1016/j.geothermics.2010.09.011

[6] Fedele R, Merenda M, Praticò FG, Carotenuto F, Corte FGD. (2018). Energy harvesting for IoT road monitoring systems. Instrumentation, Mesure, Métrologie 17(4): 605-623. http://dx.doi.org/10.3166/I2M.17.605-623

[7] Barbier E. (1997). Nature and technology of geothermal energy: A review. Renewable \& Sustainable Energy Reviews (1): 1-69. http://dx.doi.org/10.1016/S13640321(97)00001-4

[8] Pirlo MC. (2004). Hydrogeochemistry and geothermometry of thermal groudwaters from the Bidsville Track Ridge, Great Artesian Basin, South Australia. Geothermics 33(6): 743-774. http://dx.doi.org/10.1016/j.geothermics.2004.07.001

[9] Sun H, Zhang X, Zhou L, Shao X. (2018). Hydration heat and shrinkage of the support of high-performance concrete-filled steel tubes. Chemical Engineering Transactions 66: 1171-1176. http://dx.doi.org/10.3303/CET1866196

[10] Govind RR, Vishwambhar SP, Prasad JSVRK. (2018). MHD flow of Powell-Eyring nanofluid containing nanoparticles and gyrotactic microorganisms over a stretched surface. Revue des Composites et des Matériaux Avancés 28(3): 405-420. http://dx.doi.org/10.3166/RCMA.28.405-420

[11] Chandrajith R, Barth JAC, Subasinghe ND. (2013). Geochemical and isotope characterization of geothermal spring waters in Sri Lanka: Evidence for steeper than expected geothermal gradients. Journal of Hydrology 476(7): 360-369. http://dx.doi.org/10.1016/j.jhydrol. 2012.11.04

[12] Kearey P, Wei H. (1993). Geothermal fields of China. J. Volcanol. Geoth. Res. 56: 415-428. http://dx.doi.org/10.1016/0377-0273(93)90006-D

[13] Du J, Liu C, Fu B, Ninomia Y, Zhang Y, Wang C, Wang H, Sun Z. (2005). Variations of geothermometry and chemical-isotope compositions of hot spring fluids in the Rehai geothermal field, southwestern China. J. Volcanol.
Geoth. $\quad$ Res. 142: 243-261. http://dx.doi.org/10.1016/j.jvolgeores.2004.11.009

[14] Zhu M, Tong W. (1987). Surface hydrothermal minerals and their distribution in the Tengchong geothermal area, China. Geothermics 16: 181-195. http://dx.doi.org/10.1016/0375-6505(87)90065-4

[15] Fournier R.O. (1977). Chemical geothermometers and mixing models for geothermal systems. Geothermics (5): 41-50. http://dx.doi.org/10.1016/0375-6505(77)90007-4

[16] Giggenbach W.F. (1988). Geothermal solute equilibria. Derivation of Na-K-Mg-Ca bioindicators. Geochimica et Cosmochimica Acta 52(12): 2749-2765. http://dx.doi.org/10.1016/0016-7037(88)90143-3

[17] Giggenbach W.F. (1980). Geothermal gas equilibria. Geochimica et Cosmochimica Acta 44(12): 2021-2032. http://dx.doi.org/10.1016/0016-7037(80)90200-8

[18] Verma SP, Santoyo E. (1997). New improved equations for $\mathrm{Na} / \mathrm{K}, \mathrm{Na} / \mathrm{Li}$ and $\mathrm{SiO} 2$ geothermometers by outlier detection and rejection. Journal of Volcanology and Geothermal Research 79(1-2): 9-23. http://dx.doi.org/10.1016/S0377-0273(97)00024-3

[19] Giggenbach WF. (2001). Evaluation of results from the fourth and fifth IAVCEI field workshop on volcanic gases, Vulcano island, Italy and Java, Indonesia. Journal of Volcanology \& Geothermal Research 108(1): 157-172. http://dx.doi.org/10.1016/S0377-0273(00)00283-3

[20] Giggenbach W, Sheppard DS, Robinson BW. (1994). Geochemical structure and position of the Waiotapu geothermal field, New Zealand. Geothermics 23(5): 599644. http://dx.doi.org/10.1016/0375-6505(94)90022-1

[21] Giggenbach WF, Sano Y, Wakita H. (1993). Isotopic composition of helium, and $\mathrm{CO} 2$ and $\mathrm{CH} 4$ contents in gases produced along the New Zealand part of a convergent plate boundary. Geochimica Et Cosmochimica Acta 57(14): 3427-3455. http://dx.doi.org/10.1016/0016-7037(93)90549-C

[22] Kharaka MSLYK. (1982). Chemical Geothermometers Applied to Formation Waters, Gulf of Mexico and California Basins: ABSTRACT. Aapg Bulletin 66: 588. http://dx.doi.org/10.1306/03B59EAE-16D1-11D7$8645000102 \mathrm{C} 1865 \mathrm{D}$

[23] Giggenbach WF. (1988). Geothermal solute equilibria. Derivation of Na-K-Mg-Ca geoindicators. Geochimica Et Cosmochimica Acta 52(12): 2749-2765. http://dx.doi.org/10.1016/0016-7037(88)90143-3

[24] Fournier RO, Truesdell AH. (1970). Chemical indicators of subsurface temperature applied to hot spring waters of Yellowstone National Park, Wyoming, U.S.A. Geothermics 2: 529-535. http://dx.doi.org/10.1016/0375-6505(70)90051-9

[25] Fournier RO. (1979). Geochemical and hydrologic considerations and the use of enthalpy-chloride diagrams in the prediction of underground conditions in hot-spring systems. Journal of Volcanology \& Geothermal Research 5(1-2): 1-16. http://dx.doi.org/10.1016/03770273(79)90029-5 